\title{
HOW DO CLONAL PLANTLETS OF MATE RESPOND TO DIFFERENT SUBSTRATE COMPOSITIONS AND SHADING LEVELS?
}

\author{
COMO AS MUDAS CLONAIS DE ERVA-MATE RESPONDEM A DIFERENTES \\ COMPOSIÇÕES DE SUBSTRATOS E NÍVEIS DE SOMBREAMENTO?
}

\section{Nathalia PIMENTEL ${ }^{1}$; Mhaiandry Benedetti RODRIGUES ${ }^{2}$; Rejane FLORES ${ }^{3}$; Dilson Antônio BISOGNIN ${ }^{4}$}

1. Universidade Federal de Santa Maria, Departamento de Ciências Florestais, Santa Maria, RS, Brasil; 2. Universidade Federal de Santa Maria, Departamento de Ciências Florestais, Santa Maria, RS, Brasil; 3. Instituto Federal de Educação, Ciência e Tecnologia Farroupilha, Departamento de Biologia, São Vicente do Sul, RS, Brasil; 4. Universidade Federal de Santa Maria, Departamento de Fitotecnia, Santa Maria, RS, Brasil. dilson.bisognin@ufsm.br

\begin{abstract}
Mate (Ilex paraguariensis A. St.-Hil) is an arboreal species of great economic and socioenvironmental importance in South American countries. This specie presents several difficulties during seminal propagation, and studies related to plantlet production by vegetative propagation are fundamental for obtaining homogenous mate plantations with high leaf productivity. Therefore, the present study aimed to evaluate the effects of substrate and shading levels on the morphophysiological quality of mate plantlets produced by minicuttings. Rooted mini-cuttings of four mate clones were cultivated on commercial substrate, subsurface soil and vermiculite $(2: 1: 1 \mathrm{v} / \mathrm{v} / \mathrm{v})$, commercial substrate and subsurface soil $(2: 1 \mathrm{v} / \mathrm{v})$ or subsurface soil, cattle manure and carbonized rice hulls $(2: 1: 1 \mathrm{v} / \mathrm{v} / \mathrm{v})$. After 120 days, the plantlets were randomly distributed on benches to evaluate the effects of 50 and $80 \%$ shading screens. Regardless of the clone, the commercial substrate and subsurface soil composition allowed plantlet production with satisfactory development of both aerial part and root system at 120 days of cultivation. Clone 06SM17 produced plantlets with high averages of stem diameter, shoot height, number of leaves, total length, surface area, total volume of roots, and number of root tips. Both shade levels resulted in similar stem diameters, shoot heights, numbers of leaves, and $a, b$, and total chlorophyll indices. Clonal mate plantlets with satisfactory morphophysiological quality are produced in commercial substrate and subsurface soil (2:1 v/v) under 50 and $80 \%$ shading.
\end{abstract}

KEYWORDS: Forest species. Ilex paraguariensis A. St.-Hil. Plantlet production. Vegetative propagation.

\section{INTRODUCTION}

New plantations of mate (Ilex paraguariensis A. St.-Hil.) have been established with seminal seedlings, but the production of new seedlings is hampered by a low percentage of seed germination, because embryos are usually immature and undergoing tegumentary and physiological dormancy (FOWLER; STURION; ZUFFELLATO-RIBAS, 2007). In addition, planting seminal seedlings may result in non-uniform plants and low yields of commercial mate, because of, among other factors, quality differences and high genetic variability among seedlings used for the establishment of plantations. As an alternative, asexual propagation by mini-cuttings, which is a variation of the cutting technique, results in the production of uniform plantlets of satisfactory quality with operational, technical, economic, and environmental advantages.

The production of plantlets can be directly affected by the production system, including clones, substrate composition and nursery management.
Plantlets from different clones may differ in their vegetative growth, as observed in several forest species, such as Toona ciliata (BATISTA; FURTINI NETO; DECCETTI, 2015) and hybrids of Eucalyptus grandis $\times E$. urophylla and $E$. camaldulensis $\times E$. spp. (REIS et al., 2006), because they present distinct adaptation strategies (BATISTA; FURTINI NETO; DECCETTI, 2015) and differentiated nutrient use efficiencies (REIS et al., 2006) of the soil or substrate.

In the selection of the substrate composition to be used in the production of forest plantlets, it is extremely important to analyze of their physical and chemical characteristics, which promote water retention and nutrient availability, respectively, to meet the specific needs of each species (CUNHA et al., 2006). Several studies have evaluated the effect of substrates on the quality of seminal mate seedlings (WENDLING; GUASTALA; DOMINGOS, 2006; WENDLING; GUASTALA; DEDECEK, 2007a; ZAVISTANOVICZ et al., 2017), and verified better growth and development 
of the plants in substrate compositions containing cattle manure (WENDLING; GUASTALA; DOMINGOS, 2006; WENDLING; GUASTALA; DEDECEK, 2007a) or subsurface soil and cattle manure (ZAVISTANOVICZ et al., 2017).

Regarding plantlet management in nurseries, care should be taken regarding exposure to sunlight, because generally, when radiation is reduced, photosynthesis, stomatal conductance, and Rubisco activity also decrease rapidly (HERAUT-BRON et al., 1999), affecting physiological processes and, consequently, plant development. However, the capacity to capture and use sunlight varies between species (SANTOS-MOURA et al., 2018), which has led researchers to study the effect of shading levels on adult mate plants grown in monoculture and subforests (RAKOCEVIC; MARTIM, 2011; CARON et al., 2014), as well seminal mate seedlings in nursery conditions (POLETTO et al., 2010; FERMINO JUNIOR; FOCKINK, 2017).

In this context, it is known that both substrate composition (WENDLING; GUASTALA; DOMINGOS, 2006; WENDLING; GUASTALA; DEDECEK, 2007a; ZAVISTANOVICZ et al., 2017) and light levels interfere directly in the development of seminal mate plants (POLETTO et al., 2010; RAKOCEVIC; MARTIM, 2011; CARON et al., 2014), but there is limited information in the literature on the influence of these factors on the quality of mate plantlets produced by mini-cutting. Various studies on vegetative propagated mate plants have emphasized the adventitious rooting of minicuttings (BRONDANI et al., 2007; BRONDANI et al., 2008; WENDLING; DUTRA; GROSSI, 2007b; KRATZ et al., 2015; SÁ et al., 2018) and growth and productivity of plants under field conditions (SANTIN et al., 2015), but not elucidated the factors that interfere in the mate plantlets production in nursery conditions.

Considering that for the establishment of homogenous forest plantations with high leaf productivity, the use of clonal plantlets with adequate quality is fundamental and this parameter can be influenced by several factors of the productive process, this study aimed to evaluate the effects of substrate composition and shading level on the morphophysiological quality of plantlets the four mate clones that were produced by mini-cuttings.

\section{MATERIAL AND METHODS}

The experiments were conducted using mate plant clones 06SM17, 06SM15, and 06SM12 derived from the in vitro germination of zygotic embryos, and the clone 10SM07was derived from cuttings of epicormic shoots from a $\sim 20$-year-old plant (PIMENTEL et al., 2017). Sprouts from mate ministumps that had been maintained in a mini-clonal hedge in a closed soilless system were collected in July 2014 and sectioned into mini-cuttings with one bud $\sim 2.0-\mathrm{cm}$-long and one leaf reduced to $50 \%$ of its original area. The mini-cuttings were cultivated in polystyrene trays containing pine-bark-based commercial substrate, vermiculite and coarse sand (1:1:1 v/v/v) (PIMENTEL et al., 2017).

Trays containing the mini-cuttings of the four mate clones were maintained in a wet chamber with a relative air humidity of $\sim 85 \%$ for 60 days. The rooted mini-cuttings were planted in $1500-\mathrm{cm}^{3}$ polyethylene bags $(22 \times 15 \mathrm{~cm})$ (PIMENTEL et al., 2017) with three substrate compositions. The substrates were pine-bark-based commercial substrate, subsurface soil and medium-particle-size vermiculite $(2: 1: 1 \mathrm{v} / \mathrm{v} / \mathrm{v})$, pine-bark-based commercial substrate and subsurface soil $(2: 1 \mathrm{v} / \mathrm{v})$ and subsurface soil, cattle manure and carbonized rice hulls $(2: 1: 1 \mathrm{v} / \mathrm{v} / \mathrm{v})$. The subsurface soil was classified as an Argosol, and its subsurface layer was approximately $15 \mathrm{~cm}$ below the soil surface. The cattle manure was subjected to a stabilization process before use. Physical characterization of the different substrate compositions (Table 1) was performed by the Laboratory of Horticulture Substrate Analysis of the Federal University of Rio Grande do Sul, according to Normative Instruction $\mathrm{N}^{0} 17$ of the Ministry of Agriculture, Livestock and Supply (BRASIL, 2007). Chemical analyses of the different substrate compositions (Table 1) were conducted by the Soil Laboratory of the Federal University of Santa Maria according to the method proposed by Tedesco et al. (1995). 
Table 1. Physical and chemical characteristics of substrate compositions used in the production of mate plantlets clonal (Ilex paraguariensis).

\begin{tabular}{|c|c|c|c|}
\hline Characteristic & $\begin{array}{r}\mathrm{CS}+\mathrm{SS}+\mathrm{V}^{*} \\
(2: 1: 1 \mathrm{v} / \mathrm{v} / \mathrm{v})\end{array}$ & $\begin{array}{l}\mathrm{CS}+\mathrm{SS} \\
(2: 1 \mathrm{v} / \mathrm{v})\end{array}$ & $\begin{array}{l}\mathrm{SS}+\mathrm{CM}+\mathrm{CRH} \\
(2: 1: 1 \mathrm{v} / \mathrm{v} / \mathrm{v})\end{array}$ \\
\hline $\mathrm{pH} \mathrm{H}_{2} \mathrm{O}^{* *}$ & 5.28 & 4.97 & 6.74 \\
\hline Aeration space $(\%)$ & 14.89 & 20.79 & 20.45 \\
\hline Dry density $\left(\mathrm{kg} \mathrm{m}^{-3}\right)$ & 530.12 & 590.23 & 723.90 \\
\hline Total porosity ( $\%)$ & 73.63 & 73.51 & 67.60 \\
\hline Available water $(\%)$ & 18.98 & 20.27 & 24.00 \\
\hline Remaining water (\%) & 38.47 & 33.73 & 23.15 \\
\hline $\begin{array}{l}\text { Electrical conductivity (mS } \\
\left.\mathrm{cm}^{-1}\right)\end{array}$ & 0.66 & 0.89 & 0.46 \\
\hline Clay $(\%)$ & 15.00 & 18.00 & 19.00 \\
\hline Organic matter $(\%)$ & 11.90 & 12.90 & 15.70 \\
\hline Cation exchange capacity & 14.90 & 24.50 & 27.40 \\
\hline Phosphorus $\left(\mathrm{mg} \mathrm{L}^{-1}\right)$ & 57.00 & 75.40 & 200.10 \\
\hline Potassium $\left(\mathrm{mg} \mathrm{L}^{-1}\right)$ & 224.00 & 244.00 & 400.00 \\
\hline $\operatorname{Zinc}\left(\mathrm{mg} \mathrm{L}^{-1}\right)$ & 2.90 & 2.20 & 8.80 \\
\hline
\end{tabular}

${ }^{*} \mathrm{CS}=$ commercial substrate, $\mathrm{SS}=$ subsurface soil, $\mathrm{V}=$ vermiculite, $\mathrm{CM}=$ cattle manure, $\mathrm{CRH}=$ carbonized rice hulls. ${ }^{* *}$ Determined in water, dilution $1: 5(\mathrm{v} / \mathrm{v})$.

During the experimental period, plantlets of four clones grown in the different substrate compositions were placed on benches in a screen house with $30 \%$ nylon shading and irrigated daily with a hand irrigator $\left(3.6 \mathrm{~L} / \mathrm{m}^{2}\right)$. The experiment had a completely randomized $4 \times 3$ factorial design (clones $\times$ substrate compositions), with five replicates of four plantlets each, totaling 240 plantlets. After 30, 60, 90, and 120 days of cultivation, the plantlets' survival percentages, stem diameters, shoot heights, shoot height and stem diameter ratios and numbers of leaves were determined. Shoot height was measured from the substrate to the apex of the last-formed leaf, and stem diameter was measured at substrate level with a digital calliper.

After 120 days of cultivation, three plantlets were randomly selected from each treatment to determine their shoot and root dry masses. The plantlets were washed in tap water, sectioned at substrate level and the shoots and roots placed in a circulating air oven at $105{ }^{\circ} \mathrm{C}$ until a constant mass was obtained. The dried roots were scanned in an Epson 11000XL scanner, and root quantification was performed using WinRhizo Pro ${ }^{\circledR}$ software, which measured the total length, surface area, total volume and number of root tips. Then, the relationship between shoot and root dry masses was investigated, in order to obtain the Dickson quality index (DQI; DICKSON; LEAF; HOSNER, 1960) according to the following equation (Eq. 1):

$$
\mathrm{DQI}=\frac{\mathrm{TDM}(\mathrm{g})}{\frac{\mathrm{SH}(\mathrm{Cm})}{\mathrm{SD}(\mathrm{mer})}+\mathrm{RSR}}
$$

TDM-total dry mass of plantlets (g); SHshoot height $(\mathrm{cm})$; SD- stem diameter $(\mathrm{mm})$; RSRshoot and root dry masses ratio.

To evaluate the effect of shading levels, the surviving plantlets from the previous experiment were randomly distributed on benches to evaluate the effect of 50 or $80 \%$ shading screens, without acclimation. According to the Köppen classification, the local climate is Cfa with a monthly mean rainfall of 100 to $170 \mathrm{~mm}$ (ALVAREZ et al., 2013). The experiment was conducted with a completely randomized design, with two treatments containing 10 replicates of 10 plantlets each, totaling 200 plantlets. After 30, 60, 90, and 120 days of cultivation at different shading levels, the plantlets' survival percentages, stem diameters, shoot heights, shoot height and stem diameter ratios, numbers of leaves, the plantlets' $a, b$ and total chlorophyll indices were determined. Chlorophyll determination was performed using a chlorophyllmeter (ClorofiLOG $^{\mathbb{B}}$, Falker Agricultural Automation, Brazil) on sunny days between 8:00 a.m. and 10:00 a.m. analyzing the second, fully expanded leaf from the apex to the base of each plantlet. The data are expressed as the Falker Chlorophyll Index (FCI), the value of which is proportional to the absorbance of chlorophyll.

To meet the assumptions of normality, percentage data from both experiments were transformed to arcsine $\sqrt{x / 100}$ and count and length data to $\sqrt{x+0.5}$ before being subjected to an analysis of variance. Significant differences between treatment means were compared by Tukey test at the 5\% significance level. 


\section{RESULTS AND DISCUSSION}

There was no significant interaction $(\mathrm{p}>$ 0.05 ) between the substrate compositions and mate clones for all traits at 30,60, 90 and 120 days of cultivation (Figure 1; Figure 3). Up to 60 days of cultivation, all of the substrate compositions resulted in similar plantlet morphological quality (Figure 1A; Figure 1B; Figure 1C; Figure 1D). However, at 90 days of cultivation, the subsurface soil, cattle manure and carbonized rice hulls compositions facilitated the production of plantlets
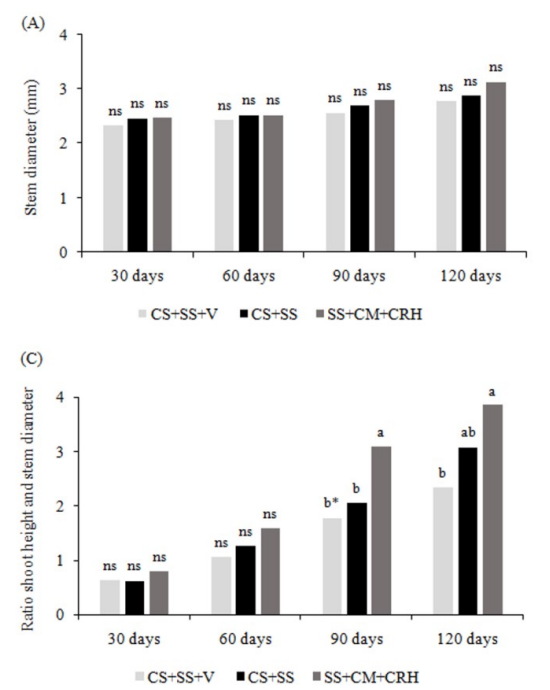

of all the clones studied with greater morphological quality, as they presented a higher ratio between shoot height and stem diameter (Figure 1C) and number of leaves (Figure 1D), without statistical differences between commercial substrate and subsurface soil composition at 120 days of cultivation (Figure 1C; Figure 1D). In production of mate seminal seedlings, high morphological-trait values were observed when grown on substrates containing organic components, such as cattle manure and subsurface soil (ZAVISTANOVICZ et al., 2017).
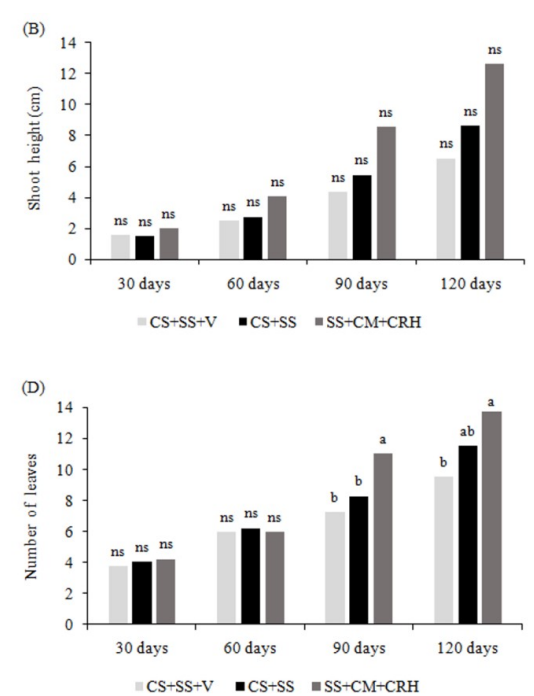

Figure 1. Stem diameter (A), shoot height (B), ratio between shoot height and stem diameter (C) and number of leaves (D) in mate (Ilex paraguariensis) plantlets produced by mini-cuttings, cultivated in different substrate compositions and evaluated at 30, 60, 90 and 120 days. $\mathrm{CS}=$ commercial substrate, $\mathrm{SS}=$ subsurface soil, $\mathrm{V}=$ vermiculite, $\mathrm{CM}=$ cattle manure, $\mathrm{CRH}=$ carbonized rice hulls. ${ }^{*}$ Treatments followed by the different letters are significantly different according to a Tukey test at the 5\% significance level. ${ }^{\text {ns }}$ Not significant.

Larger development of the aerial part of clonal plantlets cultivated in subsurface soil, cattle manure, and carbonized rice hulls and commercial substrate and subsurface soil composition (Figure 1C; Figure 1D) can be related to the physical characteristics of these substrate compositions, such as aeration space and dry density, which had higher values than the commercial substrate, subsurface soil and vermiculite combination (Table 1). High dry density can directly interfere with the fixation of plantlets, while high aeration space values facilitate oxygen diffusion, promoting the development of aerial parts of the plantlets. Thus, lower dry density may have resulted in weak fixation of plantlets in the substrate and high water retention capacity at lower voltages (MAEDA et al., 2007) and, therefore, a lower percentage of water availability (Table 1), requiring a high frequency of plant irrigation when cultivated using a combination of commercial substrate, subsurface soil, and vermiculite combination. Caldeira et al. (2013) also observed that the addition of vermiculite reduced the water availability in the composition of the substrates. As in the present study, irrigation frequency was the same for all treatments, in commercial substrate, subsurface soil and vermiculite combination less development of mate plantlets could have occurred, caused by water stress.

Regardless of clone, plantlets grown in subsurface soil, cattle manure, and carbonized rice hulls presented the highest average value for the relationship between shoot and root dry mass (Figure 2A). However, plantlets grown in this substrate composition had lower total length (Figure 2B), surface area (Figure 2C), total root volume (Figure 2D) values than plantlets cultivated in commercial substrate, subsurface soil and 
vermiculite and those grown in commercial substrate and subsurface soil. It is possible that the lowest root growth in the composition containing cattle manure occurred due a combination presenting higher values of the chemical characteristics, as percentage of clay, organic matter and cation exchange capacity (Table 1). The high cation exchange capacity is indicative of fertility, as many substrates present cations that are nutrients,
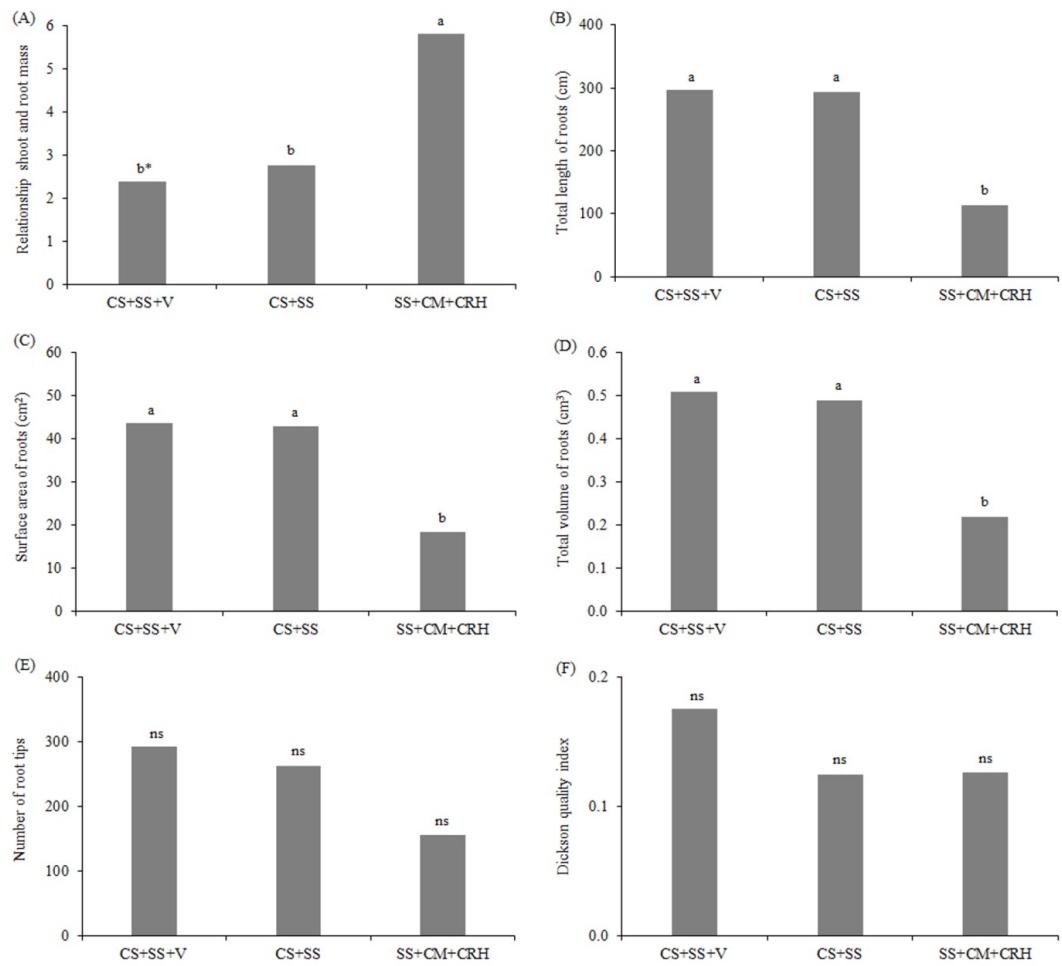

Figure 2. Relationship between shoot and root dry mass (A), total length (B), surface area (C), total volume (D), number of root tips (E) and the Dickson quality index (F) of mate (Ilex paraguariensis) plantlets cultivated for 120 days in different substrate compositions. $\mathrm{CS}=$ commercial substrate, $\mathrm{SS}=$ subsurface soil, $\mathrm{V}=$ vermiculite, $\mathrm{CM}=$ cattle manure, $\mathrm{CRH}=$ carbonized rice hulls. ${ }^{*}$ Treatments followed by the different letters are significantly different according to a Tukey test at the 5\% significance level. ${ }^{\text {ns }}$ Not significant.

The subsurface soil, cattle manure and carbonized rice hulls composition also had the highest concentration of zinc $\left(8.80 \mathrm{mg} \mathrm{L}^{-1}\right.$; Table 1$)$, which may have resulted in less root development in the plantlets grown in this composition, at 120 days of cultivation (Figure 2B; Figure 2C; Figure 2D). Zinc concentrations $>1.0 \mathrm{mg} \mathrm{L}^{-1}$ were toxic for Allium cepa L. growth, affecting mitosis and reducing root development by $50 \%$ (PALACIO et al., 2005). The phytotoxic effects of this micronutrient were also observed in the development of forest species seedlings Corymbia citriodora, Eucalyptus saligna, and E. dunnii, reducing root development by $32 \%, 30 \%$, and $93 \%$, respectively, when cultivated in $980 \mathrm{mg} \mathrm{kg}^{-1}$ of soil (SILVA et al., 2015). However, the threshold of toxicity varies widely among species, and limited information was found in the literature regarding the mate plantlets.

Regarding DQI, the plantlets cultivated in the three substrate compositions studied had values that ranged from 0.12 to 0.17 at 120 days of cultivation (Figure 2F). The DQI must have a minimum value of 0.20 (HUNT, 1990), so that none of the treatments analyzed is within the ideal. However, this ideal DQI value was based on the quality of Pseudotsuga menziesii (Mirbel Franco) and Picea abies (L. Karst.) seedlings and may not be the most suitable for the species analyzed in the present study. Pimentel et al. (2017) observed DQI values of 0.07 to 0.10 in mate plantlets obtained by zinc concentration that limits the root growth of 
mini-cutting and cultivated in different containers at 120 days of cultivation, which proves that the ideal range of DQI for mate is inferior to that recommended by Hunt (1990).

In choosing the ideal substrate compositions for the production of plantlets we must analyze the morphophysiological quality of the plantlets, and costs of each component and impact of its extraction, to reduce them, since plantlets of forest species present low added value (PIMENTEL et al., 2016). In general, in the present study, the commercial substrate and subsurface soil composition resulted in the production of plantlets with higher development in both the aerial parts and root systems (Figure 1; Figure 2), with low production costs (PINHO et al., 2018), and was recommended for the production of plantlets of clonal mate originated from mini-cutting. However, it should be noted that the component subsurface soil should be used with caution, as its extraction without adequate management criteria can damage the environment.

Regardless of substrate composition, there was no significant difference $(p>0.05)$ among the mate clones in their survival percentages, with a mean of $91.2 \%$ of live plantlets after 120 days of cultivation. Plantlet survival above $90 \%$ can be considered high, because in an experiment conducted with seminal mate seedlings, Wendling, Guastala and Dedecek (2007a) reported 60\% survival, indicating that in the present study, the management practices were adequate and the environmental conditions favorable for plantlet growth and development.

Mate plantlets from mini-cuttings presented ratio between shoot height and stem diameter ranged from 2.46 to 3.91 at 120 days (Figure $3 \mathrm{~A}$ ), indicating that the plantlets of the four clones were at growth equilibrium, because the values were less than 10 (BIRCHLER et al., 1998). However, the plantlets of clones 06SM12 and 06SM17 showed greater aerial part development, since they presented the highest average stem diameters (Figure 3B), shoot height (Figure 3C), and number of leaves (Figure 3D). In addition, plantlets of clone 06SM17 did not differ significantly from the other genetic materials in the relationships between shoot and root dry mass (Figure 4A) and Dickson quality index (Figure 4F), but presented greater root-growth traits, with the highest total length (Figure 4B), surface area (Figure 4C), total volume (Figure 4D), and number of root tips (Figure 4E) at 120 days of cultivation. Studies have also found differences in growth of the aerial part and root system of plants of forest species derived from differentiated genetic materials (REIS et al., 2006; BATISTA; FURTINI NETO; DECCETTI, 2015), which were attributed to differences in nutritional efficiency of clones. Thus, future studies aiming to characterize the four mate clones regarding the efficiency of macronutrient absorption, translocation, and utilization are fundamental for the selection of clones obtained by mini-cutting.

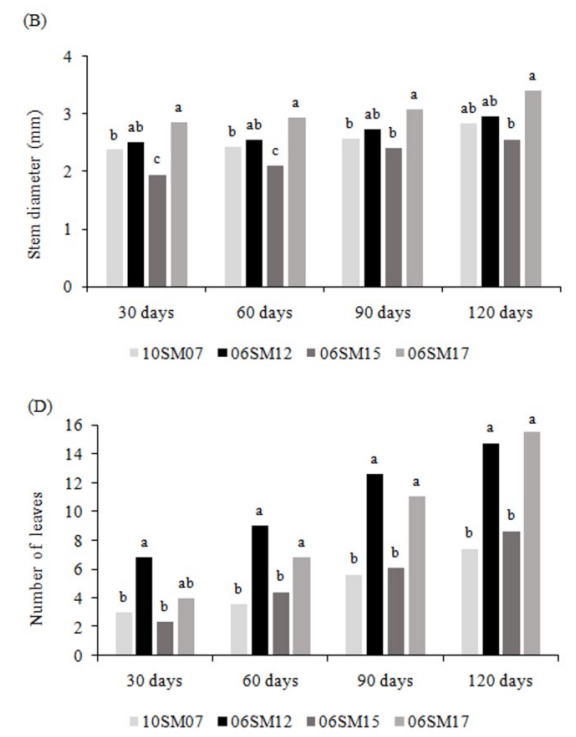

Figure 3. Ratio between shoot height and stem diameter (A), stem diameter (B), shoot height (C) and number of leaves (D) in plantlets of four clones of mate (Ilex paraguariensis) produced by mini-cuttings and evaluated at 30,60, 90 and 120 days. "Treatments followed by the different letters are significantly different according to a Tukey test at the $5 \%$ significance level. ${ }^{\text {ns }}$ Not significant. 
In the implantation of mate commercial plantations, it is fundamental to use plantlets from clones, such as 06SM17, which features a larger root system, but also higher growth of the aerial part (Figures 3 and 4), as the leaves of this species are its commercial product. Although the trend of superiority of mate genetic material under nursery conditions to remain in field conditions is poorly understood, it is known that the plantlet clone 06SM17 is more suitable for environmental stress conditions, since it is tolerant to damage by insects or torrential rains, as well as can reach greater depths in the soil to obtain water and nutrients, which may result in a higher survival and development rate of the plants of this genetic material in commercial plantations.
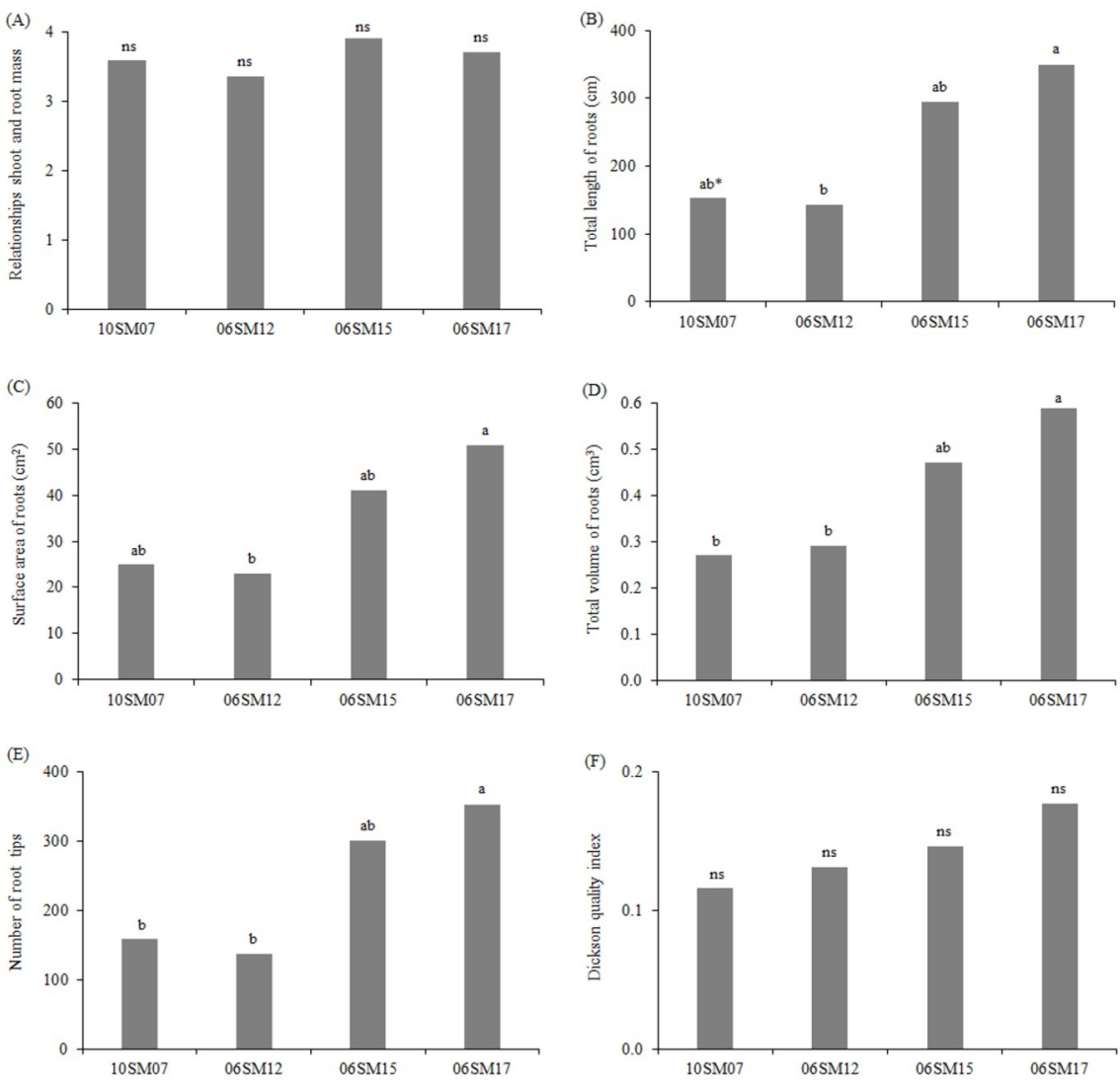

Figure 4. Relationships between shoot and root dry mass (A), total length (B), surface area (C), total volume (D), number of root tips(E) and the Dickson quality index (F) in plantlets of four clones of mate (Ilex paraguariensis) at 120 days of cultivation. ${ }^{*}$ Treatments followed by the different letters are significantly different according to a Tukey test at the $5 \%$ significance level. ${ }^{\text {ns }}$ Not significant.

Mate is a shade-grown species that grows naturally under the forest canopy, and can survive and develop under high levels of shading (POLETTO et al., 2010). In the present study, high levels of shading $(50 \%$ and $80 \%)$ did not affect the survival percentage (Figure 5A), stem diameter (Figure 5B), shoot height (Figure 5C), number of leaves (Figure 5D), chlorophyll index $a$ (Figure 5E), chlorophyll index $b$ (Figure 5F), chlorophyll index total (Figure 5G) and relationship between chlorophyll index $a$ and $b$ (Figure 5H) in mate plantlets, regardless of substrate compositions and clone, throughout the experimental period. Similar results were observed in Myrtus communis L. (MENDES; GAZARINI; RORIGUES, 2001) and Torreya grandis seedlings (TANG et al., 2015), which showed no significant differences in the chlorophyll index when cultivated at high levels of shading.

Physiological and anatomical modifications can occur when species are exposed to different levels of shading, expressing their phenotypic plasticity. However, studies have shown that shadetolerant species with less plasticity do not exhibit or exhibit reduced adaptive modifications (PAQUETTE; BOUCHARD; COGLIASTRO, 2007; VALLADARES; NIINEMETS, 2008), as observed in mate plantlets produced by minicuttings (Figure 5). Similarly, Fermino Junior and Fockink (2017) observed reduced adaptive modifications, maintaining anatomical similarity (stomatal density, polar and equatorial diameter, 
pore length) in seminal seedlings of mate grown in different shade levels. This reduced phenotypic plasticity comprises a general set of intrinsic characteristics of shade-tolerant species associated with conservative resource use and a high tolerance to low-light stress (GRIME; MACKEY, 2002).
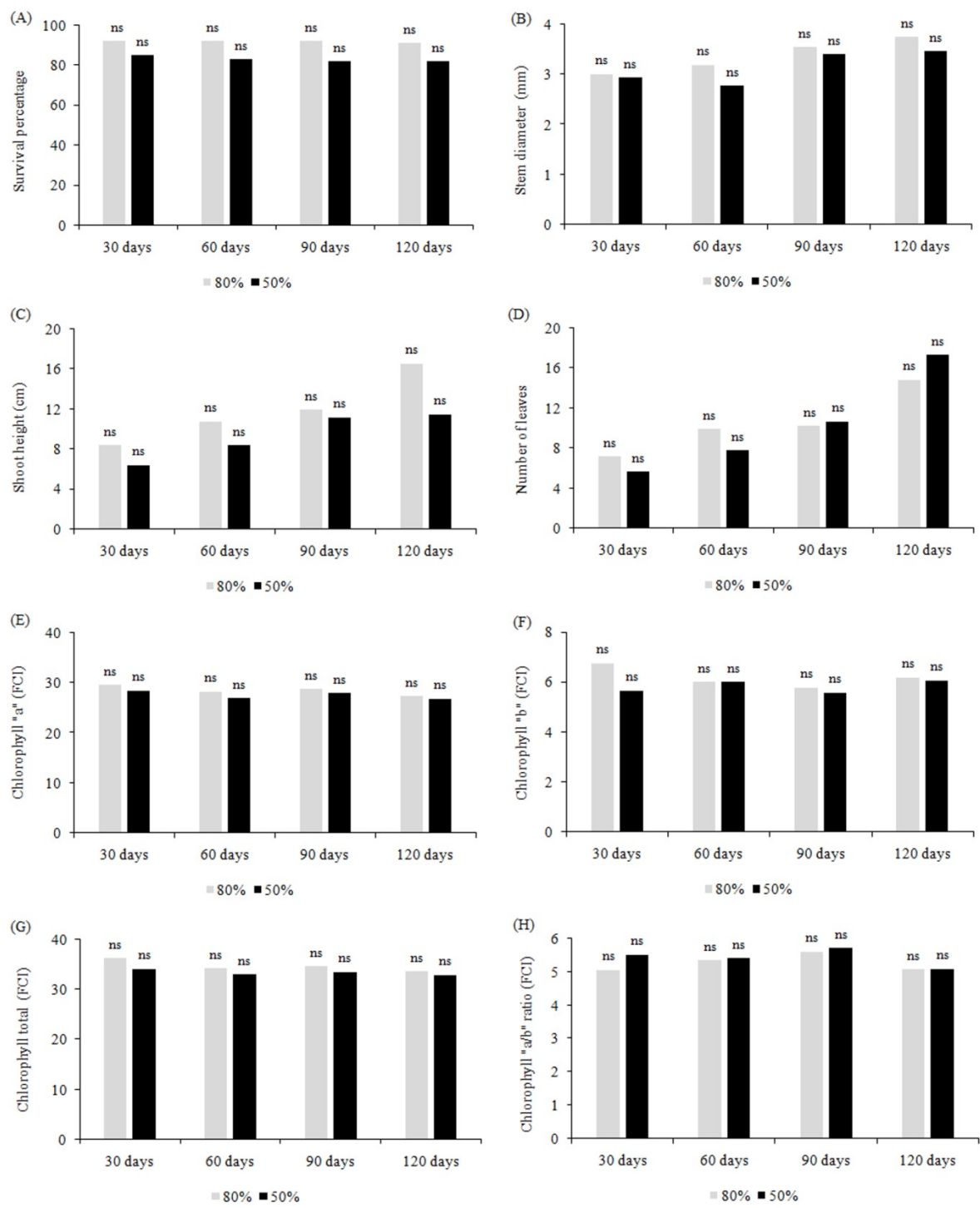

Figure 5. Survival percentage (A), stem diameter (B), shoot height (C), number of leaves (D), chlorophyll index $a(\mathrm{E})$, chlorophyll index $b(\mathrm{~F})$, chlorophyll index total $(\mathrm{G})$ and relationship between chlorophyll index $a$ and $b(\mathrm{H})$ of mate (Ilex paraguariensis) plantlets produced by mini-cuttings, cultivated at different levels of shade and evaluated at 30, 60, 90 and 120 days of cultivation. FCI $=$ Falker Chlorophyll Index. ${ }^{\text {ns }}$ Not significant according to the F test.

The present study demonstrated that mate plantlets produced by mini-cuttings presented efficient absorption of chlorophyll in 50\% and $80 \%$ of shading, which possibly results adequate photosynthetic rate of the plants. This is evidenced by the satisfactory development of the aerial part in both levels of shading studied (Figure 5), which were higher than those observed in mate plantlets also produced by mini-cutting in four different times during the year (PIMENTEL et al., 2017). Similar results have been obtained with seminal mate seedlings, which exhibited greater shoot development when grown under high levels of shading (POLETTO et al., 2010).

In general, the results of this study suggested that commercial substrate and subsurface soil composition should be used for the production of mate plantlets by mini-cuttings. Plantlets of the 06SM17 clone stood out from the other genetic materials regarding the growth of both the aerial part and root system. Clonal plantlets of this species presented suitable development in high levels of 
shading (50\% and 80\%) in nursery conditions, demonstrating that these plants will possibly present greater survival and initial development when planted in environments under cover, and can be used in plantations with other more light-demanding species. Thus, the present study elucidated some of the factors that influence the productive process of mate plantlets by mini-cuttings, resulting in plants with satisfactory morphophysiological quality, possibly in less replanting, and reduced labor costs in the establishment of forest plantations.

\section{CONCLUSIONS}

Substrate composition affected the morphophysiological quality of mate plantlets produced by mini-cuttings, and commercial substrate and subsurface soil $(2: 1 \mathrm{v} / \mathrm{v})$ was the most appropriate composition.

Mate clones differed in the morphophysiological quality of plantlets produced by mini-cuttings, with 06SM17 showing enhanced development of the aerial part and root system.

Mate plantlets obtained from mini-cuttings could be produced in both $50 \%$ and $80 \%$ shade.

\section{ACKNOWLEDGEMENTS}

The authors are grateful to the Brazilian Council for the Improvement of Higher Education and the National Council for Scientific and Technological Development for scholarships.

RESUMO: A erva-mate (Ilex paraguariensis A. St.-Hil) é espécie arbórea de grande importância econômica e socioambiental para os países da América do Sul, que apresenta diversas dificuldades de propagação utilizando sementes, sendo os estudos relacionados à produção de mudas dessa espécie por propagação vegetativa fundamentais para a obtenção de ervais homogêneos e com alta produtividade foliar. Diante desse contexto, o presente estudo objetivou avaliar o efeito das composições de substratos e dos níveis de sombreamento na qualidade morfofisiológica das mudas de erva-mate produzidas por miniestaquia. Miniestacas enraizadas de quatro clones foram cultivadas em substrato comercial, solo de subsolo e vermiculita $(2: 1: 1 \mathrm{v} / \mathrm{v} / \mathrm{v})$, substrato comercial e solo de subsolo $(2: 1 \mathrm{v} / \mathrm{v})$ ou solo de subsolo, esterco bovino e casca de arroz carbonizada $(2: 1: 1 \mathrm{v} / \mathrm{v} / \mathrm{v})$. Após 120 dias, as mudas foram aleatoriamente distribuídas em bancadas para avaliar o efeito do sombreamento de 50 e $80 \%$. Independentemente do clone, a composição substrato comercial e solo de subsolo permitiu a produção de mudas com desenvolvimento satisfatório tanto da parte aérea, quanto do sistema radicular aos 120 dias de cultivo. O clone 06SM17 possibilitou a produção de mudas com altas médias de diâmetros de colo, altura da parte aérea, número de folhas, comprimento total, área superficial, volume total de raízes e número de extremidades das raízes. Os níveis de sombreamento não afetaram o diâmetro de colo, a altura da parte aérea, o número de folhas e os índices de clorofila $a, b$ e total. Mudas clonais de erva-mate com satisfatória qualidade morfofisiológica podem ser produzidas em substrato comercial e solo de subsolo (2:1 v/v) em ambiente com $50 \%$ ou $80 \%$ sombreamento.

PALAVRAS-CHAVE: Espécie florestal. Ilex paraguariensis A. St.-Hil. Produção de mudas. Propagação vegetativa.

\section{REFERENCES}

ALVAREZ, C. A.; STAPE, J. L.; SETELHAS, P. C.; GONÇALVES, J.; SPAROVEK, G. Köppen’s climate classification map for Brazil. MeteorologischeZeitschrift, Stuttgart, v. 22, n. 6, p. 711-728, 2013. https://doi.org/10.1127/0941-2948/2013/0507.

BATISTA, R. O.; FURTINI NETO, A. E.; DECCETTI, S. F. C. Eficiência nutricional em clones de cedroaustraliano. Scientia Forestalis, Piracicaba, v. 43, n. 107, p. 647-655, 2015.

BIRCHLER, T.; ROSE, R.W.; ROYO, A.; PARDOS, M. La planta ideal: revision del concepto, parámetros definitorios e implementaction practica. Investigacion Agraria, Sistemas y Recursos Forestales, Madrid, v. 7, n. 1-2, p. 109-121, 1998.https://recyt.fecyt.es/index.php/IA/article/view/2806/2169. 29 Dez. 2018.

BRASIL. Ministério da Agricultura, Pecuária e Abastecimento. Instrução normativa no 17. Brasília: MAPA, 2007. 8 p. 
BRONDANI, G. E.; ARAUJO, M. A.; WENDLING, I.; SANTIN, I.; BENEDETTI, D.; ROVEDA, E. L.; ORRUTÉA, A. G. Ambiente de enraizamento e substratos na miniestaquia de erva mate. Scientia Agraria, Curitiba, v. 8, n. 3, p. 257-267, 2007. https://doi.org/10.5380/rsa.v8i3.9540.

BRONDANI, G. E.; ARAUJO, M. A.; WENDLING, I.; KRATZ, D. Enraizamento de miniestacas de ervamate sob diferentes ambientes. Pesquisa Florestal Brasileira, Colombo, n. 57, p. 29-38, 2008. https://doi.org/10.4336/2012.pfb.57.29.

CALDEIRA, M. V.; DELARMELINA, W. M.; PERONI, L.; GONÇALVES, E. O.; SILVA, A. G. Lodo de esgoto e vermiculita na produção de mudas de eucalipto. Pesquisa Agropecuária Tropical, Goiânia, v. 43, n. 2, p. 155-163, 2013. http://dx.doi.org/10.1590/S1983-40632013000200002.

CARON, B. O.; SCHMIDT, D.; MANFRON, P. A.; BEHLING, E. E.; BUSANELLO, C. Eficiência do uso da radiação solar por plantas Ilex paraguariensis A. ST. HIL. cultivadas sob sombreamento e a pleno sol. Revista Ciência Florestal, Santa Maria, v. 24, n. 2, p. 257-265, 2014. http://dx.doi.org/10.5902/1980509814563.

CUNHA, A. M.; CUNHA, G. M.; SARMENTO, R. A.; CUNHA, G. M.; AMARAL, J. F. T. Efeito de diferentes substratos sobre o desenvolvimento de mudas de Acacia sp. Revista Árvore, Viçosa, v. 30, n. 2 , p. 207-214, 2006. http://dx.doi.org/10.1590/S0100-67622006000200007.

DICKSON, A.; LEAF, A. L.; HOSNER, J. F. Quality appraisal of white spruce and white pine seedling stock in nurseries. Forest Chronicle, Mattawa, v. 36, p. 10-13, 1960. https://doi.org/10.5558/tfc36010-1.

FERMINO JUNIOR, P. C. P.; FOCKINK, G. D. Anatomia foliar de plantas jovens de erva-mate (Ilex paraguariensis A. St. Hill.) sob diferentes níveis de sombreamento. Scientia Agraria Paranaensis, Marechal Cândido Rondon, v. 16, n. 3, p. 335-341, 2017. http://dx.doi.org/10.18188/1983-1471/sap.v16n3p335-341.

FOWLER, J. A. P.; STURION, J. A.; ZUFFELLATO-RIBAS, K. C. Variação do desenvolvimento embrionário das sementes de erva-mate. Pesquisa Florestal Brasileira, Colombo, n. 54, p. 105-108, 2007. https://doi.org/10.4336/2012.pfb.54.105.

GRIME, J. P.; MACKEY, J. M. L. The role of plasticity in resource capture by plants. Evolutionary Ecology, Netherlands, v. 16, p. 299-307, 2002. https://doi.org/10.1023/A:1019640813676.

HERAUT-BRON, V.; ROBIN C.; VARLET-GRANCHER, C.; AFIF, D.; GUCKERT, A. Light quality (red:far-red ratio): does it affect photosynthetic activity, net CO2 assimilation, and morphology of young white clover leaves? Canadian Journal of Botany, v. 77, p. 1425-1431, 1999. https://doi.org/10.1139/b99-099.

HUNT, G. A. Effect of styroblock design and cooper treatment on morphology of conifer seedlings. In: ROSE, R.; CAMPBELL, S. J.; LANDIS, T. D. Target seedling symposium, meeting of the western forest nursery associations, general technichal report RM-200. 1990, Roseburg: Proceedings... Collins: United States Department of Agriculture, Forest Service, 1990. p. 218-222.

KRATZ, D.; PIRES, P. P.; STUEPP, C. A.; WENDLING, I. Produção de mudas de erva-mate por miniestaquia em substratos renováveis. Revista Floresta, Curitiba, v. 45, n. 3, p. 609-616, 2015.

https://doi.org/10.5380/rf.v45i3.36531.

LACLAU, J. P.; TOUTAIN, F.; M'BOU, A. T.; ARNAUD, M.; JOFFRE, R.; RANGER, J. The function of the superficial root mat in the biogeochemical cycles of nutrients in Congolese Eucalyptus plantations. Annals of Botany, Oxford, v. 93, p. 249-261, 2004. https://doi.org/10.1093/aob/mch035.

MAEDA, S.; DEDECEK, R. A.; AGOSTINI, R. B.; ANDRADE, G. C.; SILVA, H. D. da. Caracterização de substratos para a produção de mudas de espécies florestais elaborados a partir de resíduos orgânicos. Pesquisa Florestal Brasileira, Colombo, n. 54, p. 97-104, 2007. 
MENDES, M. M.; GAZARINI, L. C.; RORIGUES, M. L. Acclimation of Myrtus communis to contrasting Mediterranean light environments - effects on structure and chemical composition of foliage and plant water relations. Environmental and Experimental Botany, v. 45, p. 165-178, 2001. https://doi.org/10.1016/S00988472(01)00073-9.

PALACIO, S. M.; ESPINOZA-QUIÑONES, F. R.; GALANTE, R. M.; ZENATTI, D. C.; SEOLATTO, A. A.; LORENZ, E. K.; ZACARKIM, C, E.; ROSSI, N.; RIZZUTTO, M. A.; TABACNIKS, M. H. Correlation between heavy metal ions (copper, zinc, lead) concentrations and root length of Allium cepa L. in polluted river water. Brazilian Archives of Biology and Technology, Curitiba, v. 48, p. 191-196, 2005.

http://dx.doi.org/10.1590/S1516-89132005000400024.

PAQUETTE, A.; BOUCHARD, A.; COGLIASTRO, A. Morphological plasticity in seedlings of three deciduous species under shelterwood under-planting management does not correspond to shade tolerance ranks. Forest Ecology and Management, Netherlands, v. 241, n. 1, p. 278-287, 2007.

http://dx.doi.org/10.1016/j.foreco.2007.01.004.

PIMENTEL, L. D.; BRUCKNER, C. H.; MANFIO, C. E.; MOTOIKE, S. Y.; MARTINEZ, H. E. P. Substrate, lime, phosphorus and topdress fertilization in macaw palm seedling production. Revista Árvore, Viçosa, v. 40, n. 2, p. 235-244, 2016. http://dx.doi.org/10.1590/0100-67622016000200006.

PIMENTEL, N.; LENCINA, K. H.; PEDROSO, M. F.; SOMAVILLA, T. M.; BISOGNIN, D. A.

Morphophysiological quality of yerba mate plantlets produced by mini-cuttings. Semina: Ciências Agrárias, Londrina, v. 38, n. 6, p. 3515-3528, 2017. http://dx.doi.org/10.5433/1679-0359.2017v38n6p3515.

PINHO, E. K. C.; LOPES, A. N. K.; COSTA, A. C.; SILVA, A. B. V.; VILAR, F. C. M.; REIS, R. G. E. Substratos e tamanhos de recipiente na produção de mudas de baruzeiro (Dipteryx alata Vog.). Ciência Agrícola, Rio Largo, v. 16, n. 1, p. 11-19, 2018. http://dx.doi.org/10.28998/rca.v16i1.4303.

POLETTO, I.; MUNIZ, M. F. B.; CECONI, D. E.; MEZZOMO, R.; RODRIGUES, J. Influência da inoculação de Fusarium spp. e níveis de sombreamento no crescimento e desenvolvimento da erva-mate. Revista Ciência Florestal, Santa Maria, v. 20, n. 3, p. 513-521, 2010. http://dx.doi.org/10.5902/198050982065.

RAKOCEVIC, M.; MARTIM, S. F. Time series in analysis of yerba-mate biennial growth modified by environment. International Journal of Biometeorology, Ohio, v. 55, p. 161-171, 2011.

http://dx.doi.org/10.1007/s00484-010-0322-4.

REIS, G. G. dos; REIS, M. G. F.; FONTAN, I. C. I.; MONTE, M. A.; GOMES, A. N.; OLIVEIRA, C. H. R. de. Crescimento de raízes e da parte aérea de clones de híbridos de Eucalyptus grandis X Eucalyptus urophylla e de Eucalyptus camaldulensis X Eucalyptus spp. submetidos a dois regimes de irrigação no campo. Revista Árvore, Viçosa, v. 30, n. 6, p. 921-931, 2006. http://dx.doi.org/10.1590/S0100-67622006000600007.

SÁ, F. P. de.; PORTES, D. C.; WENDLING, I.; ZUFFELLATO-RIBAS, K. C. Miniestaquia de erva-mate em quatro épocas do ano. Revista Ciência Florestal, Santa Maria, v. 28, n. 4, p. 1431-1442, 2018.

http://dx.doi.org/10.5902/1980509835051.

SANTIN, D.; WENDLING, I.; BENEDETTI, E. L.; MORANDI, D.; DOMINGOS, D. M. Sobrevivência, crescimento e produtividade de plantas de erva-mate produzidas por miniestacas juvenis e por sementes.

Revista Ciência Florestal, v. 25, n. 3, p. 571-579, 2015. http://dx.doi.org/10.5902/1980509819608.

SANTOS-MOURA, S. S. da; ALVES, E. U.; URSULINO, M. M.; BRUNO, R. L. A.; ANJOS NETO, A. P. dos. Effect of shading on Dimorphandra gardneriana Tul. seedling production. Bioscience Journal, Uberlândia, v. 34, n. 5, p. 1147-1157, 2018. https://doi.org/10.14393/BJ-v34n5a2018-39412. 
SILVA, F. R.; WEIRICH, S. W.; DA ROS, C. O.; SCHEID, D. L.; GROLLI, A. L.; VIEL, P. Acumulação e translocação de zinco em mudas de espécies do gênero Eucalyptus e Corymbia. Revista Brasileira de Engenharia Agrícola e Ambiental, Campina Grande, v. 19, n. 11, p. 1114-1120, 2015. http://dx.doi.org/10.1590/1807-1929/agriambi.v19n11p1114-1120.

TANG, H.; HU, Y.Y.; YU, W.W.; SONG, L.L.; WU, J. S. Growth, photosynthetic and physiological responses of Torreya grandis seedlings to varied light environments. Trees, Berlin, n. 29, p. 1011-1022, 2015. http://dx.doi.org/10.1007/s00468-015-1180-9.

TEDESCO, M. J.; GIANELLO, C.; BISSANI, C. A.; BOHNEN, H.; VOLKWEISS, S. J. Análises de solo, plantas e outros materiais. Porto Alegre: Universidade Federal do Rio Grande do Sul. 1995.

VALLADARES, F.; NIINEMETS, U. Shade tolerance, a key plant feature of complex nature and consequences. Annual Review of Ecology, Evolution and Systematics, New York, v. 39, p. 237-257, 2008. http://dx.doi.org/10.1146/annurev.ecolsys.39.110707.173506.

WENDLING, I.; GUASTALA, D.; DOMINGOS, D. M. Substratos para produção de mudas de erva-mate em sacos plásticos. Boletim de Pesquisa Florestal, Colombo, n. 52, p. 21-36, 2006.

WENDLING, I.; GUASTALA, D.; DEDECEK, R. Características físicas e químicas de substratos para produção de mudas de Ilex paraguariensis St. Hil. Revista Árvore, Viçosa, v. 31, n. 2, p. 209-220, 2007 a. http://dx.doi.org/10.1590/S0100-67622007000200003.

WENDLING, I.; DUTRA, L. F.; GROSSI, F. Produção e sobrevivência de miniestacas e minicepas de ervamate cultivadas em sistema semi-hidropônico. Pesquisa Agropecuária Brasileira, Brasília, v. 42, n. 2, p. 289292, 2007b. http://dx.doi.org/10.1590/S0100-204X2007000200019.

ZAVISTANOVICZ, T. C.; ARAUJO, M. M.; AIMI, S. C.; FLORES, R.; BERGHETTI A. L. P.; DEPONTI, G. Morphophysiological responses of Ilex paraguariensis seedlings to different substrates and fertilizations.

Revista Brasileira de Engenharia Agrícola e Ambiental, Campina Grande, v. 21, n. 2, p. 111-115, 2017. http://dx.doi.org/10.1590/1807-1929/agriambi.v21n2p111-115. 